\title{
Changes in Reserve Mobilization Caused by Salinity Could Interfere in the Initial Growth of Jatropha curcas
}

\author{
Emannuella Lira ${ }^{1}$, Joilma Souza ${ }^{2}$, Lucas Galdino ${ }^{2}$, Cristiane Macêdo ${ }^{3}$, Anselmo Silva ${ }^{1}$, Yuri Melo ${ }^{1}$, \\ Ivanice Santos ${ }^{1}$, Nair Arriel ${ }^{4}$, Carlos Meneses ${ }^{1}$ (D) and Josemir Maia ${ }^{1, *(D)}$ \\ 1 Programa de Pós-Graduação em Ciências Agrárias, Campus I, Universidade Estadual da Paraíba, Campina \\ Grande 58429-500, PR, Brazil; emannuellahayanna@gmail.com (E.L.); anselmoferreiras@hotmail.com (A.S.); \\ yurimelo86@gmail.com (Y.M.); ivaniceagrarias@gmail.com (I.S.); chmeneses@gmail.com (C.M.) \\ 2 Laboratório de Tecnologias da Produção Vegetal, Departamento de Agrárias e Exatas, Campus IV, \\ Universidade Estadual da Paraíba, Catolé do Rocha 58880-000, PR, Brazil; joilmasouza17@hotmail.com (J.S.); \\ lucas-pb2007@hotmail.com (L.G.) \\ 3 Labotatório de Estudos em Biotecnologia Vegetal, Departamento de Biologia Celular e Genética, \\ Universidade Federal do Rio Grande do Norte, Natal 59078-970, RN, Brazil; cristianemacedo@ufrnet.br \\ 4 Embrapa Algodão, Campina Grande 58428-095, PR, Brazil; nair.arriel@embrapa.br \\ * Correspondence: jmouram@servidor.uepb.edu.br; Tel.: +55-83-99668-1458
}

Citation: Lira, E.; Souza, J.; Galdino, L.; Macêdo, C.; Silva, A.; Melo, Y.; Santos, I.; Arriel, N.; Meneses, C.; Maia, J. Changes in Reserve Mobilization Caused by Salinity Could Interfere in the Initial Growth of Jatropha curcas. Sustainability 2021, 13, 7446. https://doi.org/10.3390/ su13137446

Academic Editors: Zhong-Hua Chen, Wenying Zhang, Fanrong Zeng and Fenglin Deng

Received: 28 May 2021

Accepted: 30 June 2021

Published: 2 July 2021

Publisher's Note: MDPI stays neutral with regard to jurisdictional claims in published maps and institutional affiliations.

Copyright: (C) 2021 by the authors Licensee MDPI, Basel, Switzerland. This article is an open access article distributed under the terms and conditions of the Creative Commons Attribution (CC BY) license (https:// creativecommons.org/licenses/by/ $4.0 /)$.

\begin{abstract}
Salinity in soil can affect Jatropha seedling metabolism, interfering with plant establishment. In this study, the effect of salinity on the mobilization of reserves during the development of Jatropha seedlings was tested. Two genotypes of Jatropha were used and three concentrations of $\mathrm{NaCl}$ were applied between the 4th and 8th days after germination. The effects of salinity on seedling growth, in terms of fresh and dry phytomass, ionic partition, and sugar quantification, starch, proteins, amino acids, and lipids were evaluated in cotyledon leaves, hypocotyls, and roots. There was an increase in the content of all classes of macromolecules analyzed in at least one of the organs. It is hypothesized that the hypocotyls acted as an accumulating organ of $\mathrm{Na}^{+}$. The accumulations of amino acids and protein in roots suggest that metabolic responses occurred in response to the ionic and osmotic effects of $\mathrm{NaCl}$, although this accumulation did not appear to prevent biomass losses in seedlings. Furthermore, the findings of this study demonstrate that salinity inhibits the mobilization of lipids and carbon stocks from cotyledon leaves to the rest of the plant, and together with the synthesis of proteins and amino acids that occurred primarily in roots, contributed to response of these plants to salinity.
\end{abstract}

Keywords: germination; seedling metabolism; partition of macromolecules; salinity

\section{Introduction}

Excess soil salts are among the main problems faced by world agriculture [1,2]. In Brazil, and especially in its semi-arid northeast, soil salinization becomes even more serious due to its association with the low precipitation and the high rate of evapotranspiration which are characteristic of this region [3]. Thus, salinized areas are no longer profitable for farmers and are consequently abandoned [4].

One potential alternative for the reuse of such areas is the selection and introduction of species tolerant to adverse environmental conditions [5]. In this context, perennial oleaginous plants, such as Jatropha curcas L., are compatible with the edaphoclimatic conditions of the Brazilian semiarid region due to their moderate resistance to drought and salinity [6]. In addition, this species has great economic importance, due to its medicinal and ornamental use and for biodiesel production [7].

Excess salts compromise the physiological and biochemical functions of plants, causing osmotic stress which results in disturbances of water conductance. They also cause changes in the absorption and utilization of essential nutrients and intensify the ionic 
toxicity process through the accumulation of $\mathrm{Na}^{+}$and $\mathrm{Cl}^{-}[8,9]$. In Jatropha species, there is little information regarding either the mechanisms underlying the regulation of the mobilization of reserves under salt stress, or the effects of salinity on the germination and establishment of seedlings [10].

The accumulation of reserve compounds (carbohydrates, proteins, and lipids) in seeds is one of the most important processes in the adaptation of plants to stress conditions. These reserves have the function of serving as a source of energy for the formation of carbon skeletons within the seedling tissues [11]. Salinity causes significant changes in plant metabolism, inhibiting the mobilization of reserves and altering the embryonic axis membranes, but it is essential to clarify the reason for this process [12].

There have been few studies aimed at the domestication of Jatropha, despite the potential of the oil extracted from its seeds (mainly for the production of biodiesel [13]. Little is known about the physiological and biochemical responses of Jatropha, especially when exposed to conditions of salinity during germination and seedling development, phases considered important for the stabilization and maintenance of the field crop [13].

This lack of information makes it imperative to study the damage caused by salinity during the mobilization of reserves in Jatropha tissues, since the germination and establishment phases of the seedling are crucial for the success of production [13]. Understanding such mechanisms may contribute to the domestication as well as the genetic improvement of this species, making it profitable and competitive in semiarid regions. Thus, the objective of the present study was to analyze the effect of salinity on the metabolism of reserve mobilization and partition of macromolecules in Jatropha seedlings, through the quantification of sugars, starch, proteins, amino acids, and lipids.

\section{Materials and Methods}

\subsection{Experimental Conditions, Harvesting and Ion Analysis}

The research was carried out in the Laboratório de Tecnologias da Produção Vegetal of the Universidade Estadual da Paraíba (UEPB), Campus IV in the Catole do Rocha-PB. Two Jatropha curcas L. genotypes were used: CNPAPM-X and CNPAPM-III, both belonging to the collection of the Active Germplasm Bank (AGB) maintained by UEPB and Centro Nacional de Pesquisa de Algodão (CNPA/Embrapa/FINEP/CNPq/MCTI) in the Sector of the UEPB in the same city. The acronym of the genotypes is a reference to the deposit of the specimens in the AGB of the CNPA. These genotypes were previously characterized as contrasting with regard to salinity tolerance in the germination phase [14]. Seedling cultivation was carried out in a nursery $\left(6^{\circ} 21^{\prime} 09.3^{\prime \prime} \mathrm{S}, 37^{\circ} 43^{\prime} 32.4^{\prime \prime} \mathrm{W}\right)$ with temperatures ranging from $32 \pm 5{ }^{\circ} \mathrm{C}$ (day) and $25 \pm 3{ }^{\circ} \mathrm{C}$ (night), air relative humidity of $60 \pm 15 \%$, photoperiod of $12 \mathrm{~h}$, and mean irradiance of $400 \mu \mathrm{E} \mathrm{m}^{-2} \mathrm{~s}^{-1}$.

Before sowing, the seeds were scarified with $0.5 \mathrm{~mm}$ sandpaper in the caruncle region until the endosperm appeared, and subsequently soaked in deionized water for $12 \mathrm{~h}$. After this period, 30 seeds were distributed in plastic trays, measuring $365 \times 235 \times 70 \mathrm{~mm}$, which were filled with washed sand as the substrate, according to the recommendations of Martins et al. [15] and Pascuali et al. [16]. The moisture content of the substrate was monitored by periodic weighing. Water replacement was carried out with distilled water in all the plots up to the 4 th day after sowing (DAS), maintaining the substrate moisture at $60 \%$ of the field capacity. The application of $\mathrm{NaCl}$ treatments was initiated on the 4th DAS at concentrations of 0,75 and $150 \mathrm{mM}$ until the 8 th DAS, in the protophile phase [17]. At this stage of development, the metabolism of reserve mobilization is still active [17-19] and ideal for development of this work.

On the 8th DAS, the seedlings were collected and separated into cotyledon leaves, hypocotyls, and roots. After the separation of the structures, one portion of the material was used to determine the fresh and dry mass, another portion was used for the quantification of organic molecules, and the remaining material was dehydrated in an oven at $70{ }^{\circ} \mathrm{C}$ for $48 \mathrm{~h}$ for ion quantification. The determinations of $\mathrm{Na}^{+}, \mathrm{K}^{+}$and $\mathrm{Ca}^{2+}$ were performed according to Malavolta et al. [19] as adapted by Silva et al. [13]. Samples of $50 \mathrm{mg}$ of dry 
plant tissue were extracted with $20 \mathrm{~mL}$ of boiling deionized water for $1 \mathrm{~h}$. The extracts obtained were centrifuged, and the supernatants were analyzed in a flame photometer (Micronal B462). Following the determination of the $\mathrm{Na}^{+}$and $\mathrm{K}^{+}$contents in each plant part, the $\mathrm{K}^{+} / \mathrm{Na}^{+}$ratio was calculated.

\subsection{Carbohydrate Analysis}

The measurement of the total soluble sugar (TSS) concentration was performed by the "phenol-sulfuric" method described by Dubois et al. [20]. First, $50 \mathrm{mg}$ of dry mass was added in $5 \mathrm{~mL}$ of $80 \%$ ethanol and incubated at $100{ }^{\circ} \mathrm{C}$ for $1 \mathrm{~h}$ and the supernatant was recovered and filtered on cotton. The TSS concentrations were determined based on the standard curve adjusted for increasing concentrations of D-glucose stock solution, with results expressed in $\mu \mathrm{mol} / \mathrm{g}$ of dry matter and readings being conducted using a spectrophotometer at $490 \mathrm{~nm}$ absorbance. Non-reducing and reducing carbohydrates were determined according to Morris [21] and Yemm and Willis [22], as adapted by Passos [23] using the same TSS extract. To $0.9 \mathrm{~mL}$ of the sample was added $0.1 \mathrm{~mL}$ of $30 \% \mathrm{KOH}$, and the mixture was incubated at $100{ }^{\circ} \mathrm{C}$ for $10 \mathrm{~min}$. After cooling to room temperature $\left( \pm 25^{\circ} \mathrm{C}\right), 2.5 \mathrm{~mL}$ of the anthrone reagent was added, and the solution was read using a spectrophotometer at $620 \mathrm{~nm}$. For the estimation of reducing sugars (RS), the amount of NRS was subtracted from the amount of TSS.

Starch was quantified by the method of McCready et al. [24]. For extraction, the precipitate obtained in the extraction of TSS was macerated again, this time with $1.5 \mathrm{~mL}$ of $30 \%$ perchloric acid. The material was then centrifuged at $10,000 \times \mathrm{g}$ for $10 \mathrm{~min}$, the supernatant recovered and $1 \mathrm{~mL}$ of perchloric acid added. For quantitation, $1 \mathrm{~mL}$ of the sample was added to $2.5 \mathrm{~mL}$ of the anthrone reagent, vortexed, and read at $620 \mathrm{~nm}$.

\subsection{Analysis of Proteins, Amino Acids and Lipids}

For the protein content, $200 \mathrm{mg}$ of fresh material was triturated with $2 \mathrm{~mL}$ of $50 \mathrm{mM}$ phosphate buffer ( $\mathrm{pH} 7.0)$ amended with ascorbic acid (0.1 mM), EDTA (0.1 mM), and polyvinylpyrrolidone (5\%). Extracts were centrifuged at $20,000 \times \mathrm{g}$ for $15 \mathrm{~min}$ at $4{ }^{\circ} \mathrm{C}$, and the supernatant was used for the determination of soluble proteins [25]. The total free amino acids (TFAA) concentration was determined by the method described by Peoples et al. [26]. TFAA concentrations were determined based on the standard curve adjusted for increasing concentrations of a standardized L-glutamine mixture, with the results expressed in $\mu \mathrm{mol} . \mathrm{g}^{-1}$ of dry matter and absorbance measurements were carried out using a spectrophotometer at $570 \mathrm{~nm}$.

Neutral lipids were quantified by the gravimetric method using $n$-hexane as the solvent. First, $200 \mathrm{mg}$ of dry mass was added to $8 \mathrm{~mL}$ of $\mathrm{n}$-hexane, and this mixture was then incubated in a $60{ }^{\circ} \mathrm{C}$ water bath for $5 \mathrm{~h}$ and vortexed every hour. Then, the liquid fraction was collected, and organic solvent was allowed to evaporate at room temperature in a closed chamber. The amount of lipids was estimated by simple subtraction [27].

\subsection{Statistical Analysis}

The experimental design used was completely randomized in a $2 \times 3$ factorial. The first factor corresponded to the genotypes and the second to the $\mathrm{NaCl}$ concentrations used ( 0 - control, 75, $150 \mathrm{mM}$ ) making a total of six treatments with five replications each, totaling 30 experimental units. Furthermore, all biochemical analyzes were performed with duplicates. The data were analyzed statistically using the F-Test at $5 \%$ probability. The quantitative variables were submitted to analysis of variance with unfolding degrees of freedom in the polynomial regression components. The Tukey test $(p \leq 0.05)$ was applied for qualitative factors [28]. Upper case letters indicate the differences between the doses of $\mathrm{NaCl}$ and lower-case letters indicate differences between genotypes. 


\section{Results}

\subsection{Effect of Salinity on Biomass and Ionic Partition}

The effects of salinity were observed on both the fresh weight (FW) and dry weight (DW) of cotyledon leaves, hypocotyls, and roots of Jatropha except for DW of roots in both genotypes. Significant reductions in FW were observed in leaves (Figure 1A), hypocotyls (Figure $1 \mathrm{C}$ ), and roots (Figure $1 \mathrm{E}$ ), as the $\mathrm{NaCl}$ concentrations increased for both genotypes except for the FW in the hypocotyls of CNPAPM-III as subjected to $75 \mathrm{mM}$ (Figure 1C). The reductions in $\mathrm{FW}$ in cotyledon leaves at the highest $\mathrm{NaCl}$ concentration reached values of $55.11 \%$ in the genotype CNPAPM-X and $49.55 \%$ in the CNPAPM-III; in hypocotyls, reductions of $51.47 \%$ in CNPAPM-X and $25.0 \%$ in CNPAPM-III; and in roots, reductions of $35.65 \%$ and $28.7 \%$ in CNPAPM-X and CNPAPM-III, respectively.

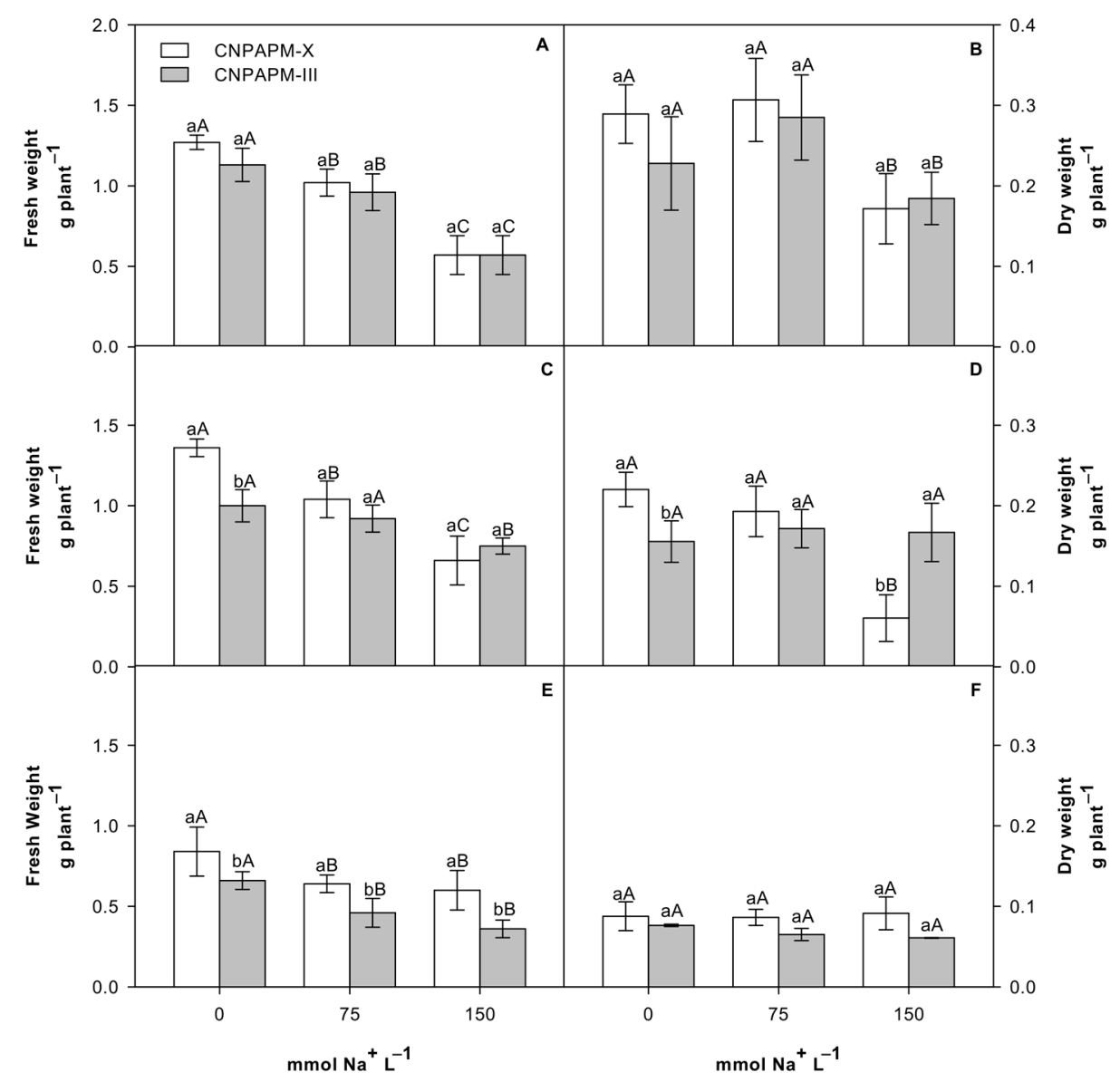

Figure 1. Fresh and dry weights of leaves $(\mathbf{A}, \mathbf{B})$, hypocotyls $(\mathbf{C}, \mathbf{D})$ and roots $(\mathbf{E}, \mathbf{F})$ of Jatropha seedlings on the 8 th DAS after exposure to 0,75 , and $150 \mathrm{mM} \mathrm{NaCl}$. Upper case letters on the bars indicate the differences between the doses of $\mathrm{NaCl}$ and lower-case letters indicate differences between genotypes tested by the Tukey test $(p \leq 0.05)$.

The DW of cotyledon leaves (Figure 1B) was reduced under the most severe saline stress $(150 \mathrm{mM})$ in both genotypes (48.78\% in CNPAPM-X and $11.93 \%$ in CNPAPM-III). In the hypocotyls (Figure 1D), a reduction in the DW index was observed only for the CNPAPM-X genotype exposed to the concentration of $150 \mathrm{mM}(72.15 \%)$ when compared to the control. In the roots (Figure 1F), the DW did not change significantly for any of the $\mathrm{NaCl}$ treatments.

Increased $\mathrm{Na}^{+}$concentrations were observed in all organs of the seedlings exposed to saline treatments, mainly at the highest $\mathrm{NaCl}$ concentration $(150 \mathrm{mM})$, independent of the genotype evaluated, except in the roots of the CNPAPM-X genotype (Table 1). In this genotype, at a concentration of $150 \mathrm{mM} \mathrm{NaCl}$, there was a reduction of $20.47 \%$ in $\mathrm{Na}^{+}$ 
content in the roots compared to the control group. In the other organs exposed to $150 \mathrm{mM}$ $\mathrm{NaCl}$, the increases in $\mathrm{Na}^{+}$levels were $32.83 \%$ for CNPAPM-X and $39.47 \%$ for CNPAPM-III in cotyledon leaves and 35.13\% for CNPAPM-X and 85.71\% CNPAPM-III in the hypocotyl region. The roots of the CNPAPM-III genotype also showed increases in $\mathrm{Na}^{+}$levels $(24.85 \%$ at the $150 \mathrm{mM}$ dose of $\mathrm{NaCl}$ ) (Table 1).

Table 1. Content of $\mathrm{Na}^{+}$and $\mathrm{K}^{+}$in leaves, hypocotyls, and roots; and the $\mathrm{K}^{+} / \mathrm{Na}^{+}$ratio in the leaves, hypocotyls and roots of Jatropha curcas L. seedlings on the 8th DAS after exposure to 0,75 and 150 $\mathrm{mM} \mathrm{NaCl}$. Upper case letters indicate the differences between the doses of $\mathrm{NaCl}$ and lower-case letters indicate differences between genotypes tested by the Tukey test $(p \leq 0.05)$.

\begin{tabular}{cccccccc}
\hline & & \multicolumn{3}{c}{ CNPAPM-X } & \multicolumn{3}{c}{ CNPAPM-III } \\
\hline & & Leaves & Hypocotyl & Root & Leaves & Hypocotyl & Root \\
\hline \multirow{2}{*}{$\mathrm{Na}^{+}$} & $0 \mathrm{mM}$ & $611.30 \mathrm{aC}$ & $652.06 \mathrm{aB}$ & $862.62 \mathrm{aA}$ & $468.67 \mathrm{bC}$ & $570.55 \mathrm{bC}$ & $883.00 \mathrm{aB}$ \\
& $75 \mathrm{mM}$ & $801.49 \mathrm{aB}$ & $978.09 \mathrm{aA}$ & $835.45 \mathrm{bA}$ & $692.81 \mathrm{bB}$ & $903.37 \mathrm{bB}$ & $937.34 \mathrm{aB}$ \\
& $150 \mathrm{mM}$ & $910.17 \mathrm{aA}$ & $1005.26 \mathrm{aA}$ & $686.02 \mathrm{bB}$ & $774.32 \mathrm{bA}$ & $1059.60 \mathrm{aA}$ & $1175.07 \mathrm{aA}$ \\
\hline \multirow{3}{*}{$\mathrm{K}^{+}$} & $0 \mathrm{mM}$ & $1149.45 \mathrm{aA}$ & $1045.75 \mathrm{aA}$ & $734.63 \mathrm{bA}$ & $1101.59 \mathrm{bA}$ & $814.40 \mathrm{bB}$ & $981.93 \mathrm{aA}$ \\
& $75 \mathrm{mM}$ & $1141.47 \mathrm{aA}$ & $1053.72 \mathrm{aA}$ & $726.65 \mathrm{bA}$ & $1037.77 \mathrm{bA}$ & $1141.47 \mathrm{aA}$ & $989.90 \mathrm{aA}$ \\
& $150 \mathrm{mM}$ & $918.11 \mathrm{aB}$ & $1141.47 \mathrm{aA}$ & $439.47 \mathrm{bB}$ & $942.04 \mathrm{aB}$ & $1213.27 \mathrm{aA}$ & $1037.77 \mathrm{aA}$ \\
\hline \multirow{3}{*}{$\mathrm{K}^{+} / \mathrm{Na}^{+}$} & $0 \mathrm{mM}$ & $1.8878 \mathrm{bA}$ & $0.1612 \mathrm{aA}$ & $0.8514 \mathrm{bA}$ & $2.3685 \mathrm{aA}$ & $0.1561 \mathrm{aA}$ & $1.1126 \mathrm{aA}$ \\
& $75 \mathrm{mM}$ & $1.4293 \mathrm{aB}$ & $0.1168 \mathrm{aB}$ & $0.8700 \mathrm{bA}$ & $1.5003 \mathrm{aB}$ & $0.1264 \mathrm{aB}$ & $1.0777 \mathrm{aA}$ \\
& $150 \mathrm{mM}$ & $1.0093 \mathrm{bC}$ & $0.1139 \mathrm{aB}$ & $0.6909 \mathrm{bB}$ & $1.2201 \mathrm{aC}$ & $0.1142 \mathrm{aB}$ & $0.8832 \mathrm{aB}$ \\
\hline
\end{tabular}

It was observed that the addition of $\mathrm{NaCl}$ in the solution reduced the $\mathrm{K}^{+}$concentrations in leaves, but only at the concentration of $150 \mathrm{mM} \mathrm{NaCl}$ and in both genotypes (also in Table 1). This reduction was $20.12 \%$ for CNPAPM-X and $14.48 \%$ for CNPAPM-III, when compared to the control group. In contrast, independent of $\mathrm{NaCl}$ levels in the solution, salinity increased $\mathrm{K}^{+}$levels in the hypocotyls of the CNPAPM-III genotype (approximately $32 \%)$. Reductions of $40.17 \%$ were also observed in the roots of the CNPAPM-X genotype after exposure to $150 \mathrm{mM} \mathrm{NaCl}$.

The $\mathrm{K}^{+} / \mathrm{Na}^{+}$ratio in the $\mathrm{NaCl}$-treated seedlings decreased in relation to their respective control groups in all organs and both genotypes, independent of $\mathrm{NaCl}$ concentration (Table 1). This decrease was directly proportional to the increase of the $\mathrm{NaCl}$ concentration in the solution only in the leaves of the seedlings in both genotypes. In this organ, despite the decrease, the ratio was higher than 1 in all treatments. In the hypocotyls, the $\mathrm{K}^{+} / \mathrm{Na}^{+}$ ratio was lower than 1 in all treatments, being the largest reduction among the organs studied. At the concentration of $150 \mathrm{mM}$, the hypocotyls of the genotype CNPAPM-X showed a reduction in the $\mathrm{K}^{+} / \mathrm{Na}^{+}$ratio of $29.31 \%$ and the CNPAPM-III genotype, $26.81 \%$. In the roots, the ratio was higher than 1 only for the CNPAPM-III genotype in the control group and in the presence of $75 \mathrm{mM} \mathrm{NaCl}$. There were reductions in the $\mathrm{K}^{+} / \mathrm{Na}^{+}$ratio in the roots of both genotypes at the $150 \mathrm{mM}$ of $\mathrm{NaCl}(18.85 \%$ in the CNPAPM-X genotype and $20.61 \%$ in the CNPAPM-III genotype).

\subsection{Changes in Carbohydrate Compartmentalization}

The content of total soluble sugars (TSS) in cotyledon leaves showed a significant increase in the CNPAPM-III genotype in both salt treatment groups $(35.26 \%$ for $75 \mathrm{mM}$ and $39.21 \%$ for $150 \mathrm{mM}$ ), and in the genotype CNPAPM-X only in moderate salt treatment $(27.09 \%$ for $75 \mathrm{mM}$ ) (Figure 2A). The non-reducing sugar levels (NRS) in cotyledon leaves (Figure 2D) increased in both genotypes, independent of $\mathrm{NaCl}$ concentration $(22.0 \%$ in CNPAPM-X and $17.0 \%$ in CNPAPM-III). Reducing sugars (RS), also in cotyledon leaves, increased by approximately $86 \%$ in the genotype CNPAPM-III for both salt treatments. In the CNPAPM-X genotype, a 33.53\% increase was observed only in the moderate salt treatment group $(75 \mathrm{mM})$. At the concentration of $150 \mathrm{mM} \mathrm{NaCl}$, however, a decrease of $19.91 \%$ was observed in relation to the control group (Figure $2 \mathrm{G}$ ). 


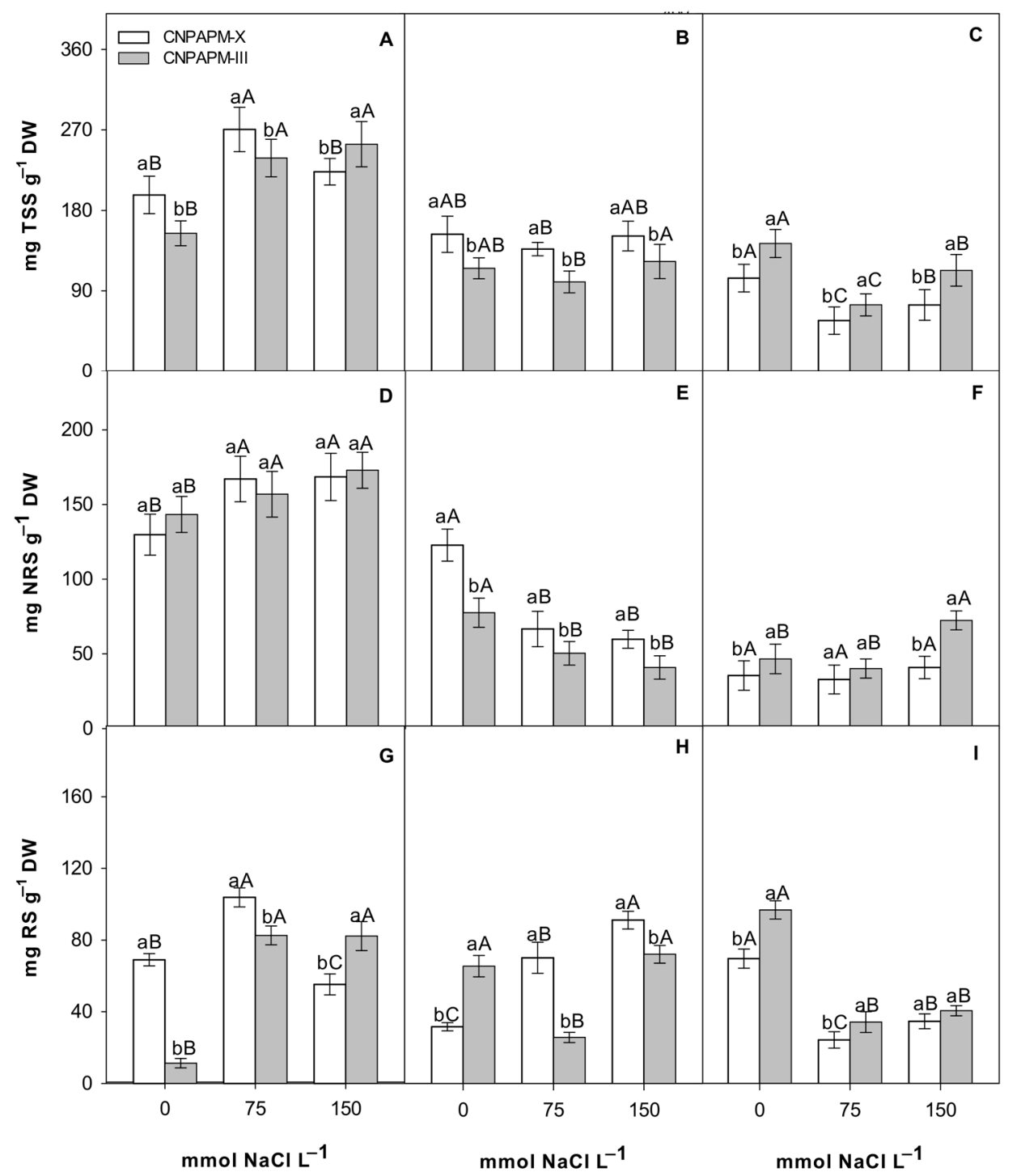

Figure 2. Total soluble sugar content (TSS), non-reducing sugars (NRS) and reducing sugars (RS) in leaves $(\mathbf{A}, \mathbf{D}, \mathbf{G})$; hypocotyl $(\mathbf{B}, \mathrm{E}, \mathbf{H})$ and $\operatorname{root}(\mathbf{C}, \mathbf{F}, \mathbf{I})$ of Jatropha seedlings on the 8th DAS after exposure to 0,75 and $150 \mathrm{mM} \mathrm{NaCl}$. Upper case letters on the bars indicate the differences between the doses of $\mathrm{NaCl}$ and lower-case letters indicate differences between genotypes tested by the Tukey test $(p \leq 0.05)$.

In the hypocotyls, no changes in TSS levels were observed in any of the salt treatments, regardless of the genotypes evaluated (Figure 2B). When evaluating the NRS content in the hypocotyls, a reduction of approximately $51 \%$ was observed for the CNPAPM-X genotype and approximately $47 \%$ for the CNPAPM-III in both salt treatments (Figure 2E). The levels of RS in the hypocotyls of the CNPAPM-III genotype were reduced by $60.8 \%$ only after exposure to moderate salt treatment $(75 \mathrm{mM})$. However, an increase of $54.86 \%(75 \mathrm{mM})$ and $65.27 \%(150 \mathrm{mM})$ in RS levels was observed in the CNPAPM-X genotype, in relation to its respective control group (Figure $2 \mathrm{H}$ ).

In the roots, there were reductions in TSS levels of $45.54 \%(75 \mathrm{mM})$ and $28.77 \%$ $(150 \mathrm{mM})$ in the CNPAPM-X genotype and reductions of approximately $48 \%(75 \mathrm{mM})$ and $21 \%(150 \mathrm{mM})$ in the CNPAPM-III genotype, both compared to their respective control groups (Figure 2C). When analyzing the NRS concentration in the CNPAPM-X genotype, there was no significant difference between the salt treatments, whereas TSS levels in roots only increased in the severe salt treatment $(150 \mathrm{mM})$ for the CNPAPM-III genotype. It 
was also observed that the levels of RS, in both genotypes studied, were reduced by the addition of $\mathrm{NaCl}$, after comparison with their respective control groups.

The content of starch in cotyledon leaves (Figure 3A) increased when $\mathrm{NaCl}$ was added to the nutrient solution, as follows: $26.21 \%$ (CNPAPM-X) and $15.13 \%$ (CNPAPM-III) at a concentration of $75 \mathrm{mM}$ and $24.39 \%$ (CNPAPM-X) and $34.94 \%$ (CNPAPM-III) at the concentration of $150 \mathrm{mM}$, when compared with the control plants. The highest starch concentration was found in the cotyledon leaves of genotype CNPAPM-III after exposure to $150 \mathrm{mM} \mathrm{NaCl}$. In the hypocotyls, a significant increase in the starch concentration in both salt treatments was observed: approximately $47 \%$ for CNPAPM-X and $22 \%$ for the CNPAPM-III genotype (Figure 3B). The starch content in the roots showed significant reductions only for the CNPAPM-III genotype $(16.81 \%$ at $75 \mathrm{mM}$ and $24.56 \%$ at $150 \mathrm{mM})$ after exposure to salt treatments (Figure 3C).

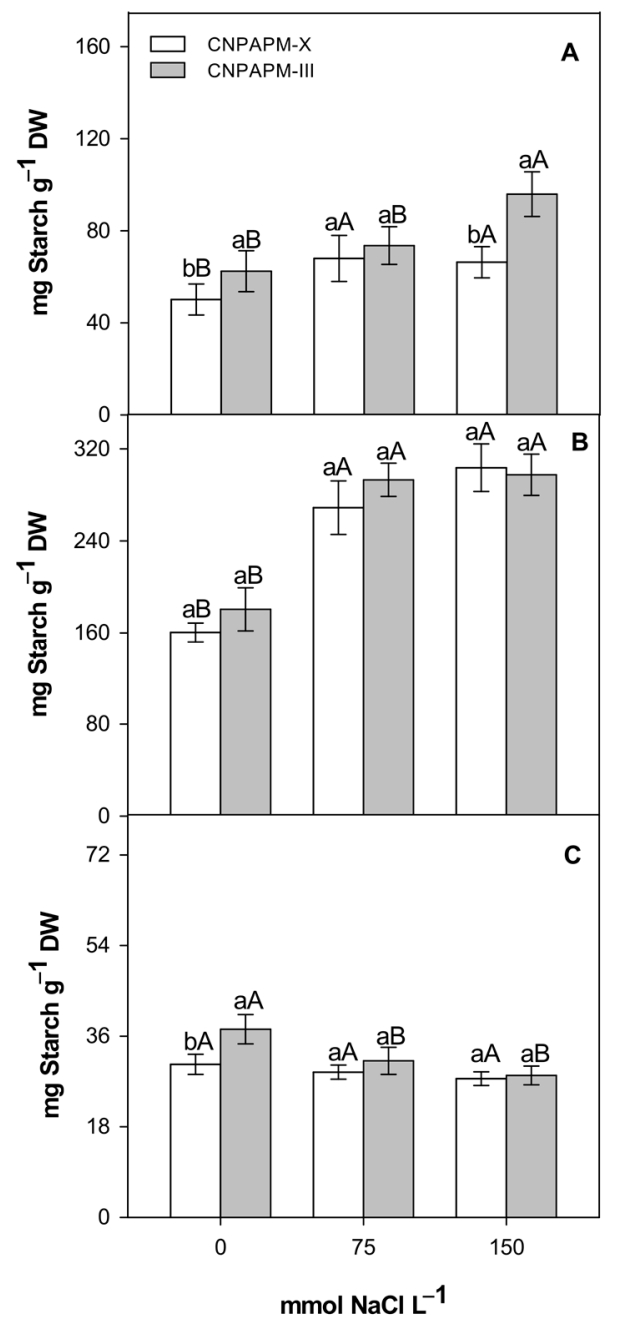

Figure 3. Content of starch in leaves (A), hypocotyls (B), and roots (C) of Jatropha seedlings on the 8th DAS after exposure to 0,75 and $150 \mathrm{mM} \mathrm{NaCl}$. Upper case letters on the bars indicate the differences between the doses of $\mathrm{NaCl}$ and lower-case letters indicate differences between genotypes tested by the Tukey test $(p \leq 0.05)$.

\subsection{Changes in Protein, Aminoacids and Lipids Partition}

Different responses were observed for the soluble protein content (SP), with respect to the organ of the seedling evaluated. In cotyledon leaves, for example, there were no significant alterations after any of the salt treatments, independent of the studied genotype (Figure 4A). When the hypocotyls were evaluated (Figure 4C), a reduction of approximately $39 \%$ in total protein levels was observed in the CNPAPM-III genotype only in the moderate 
salt treatment group $(75 \mathrm{mM})$. In the genotype CNPAPM-X, an increase of approximately $54 \%$ was observed in protein content only with the severe salt treatment $(150 \mathrm{mM})$. In roots (Figure 4E) the increase in SP levels was observed only at the $150 \mathrm{mM} \mathrm{NaCl}$ level, in both genotypes (20.55\% for CNPAPM-X and $28.6 \%$ for CNPAPM-III). In the roots of genotype CNPAPM-III (Figure 4E) there was a reduction in the content of SP at $75 \mathrm{mM}$ $\mathrm{NaCl}(31.25 \%)$.

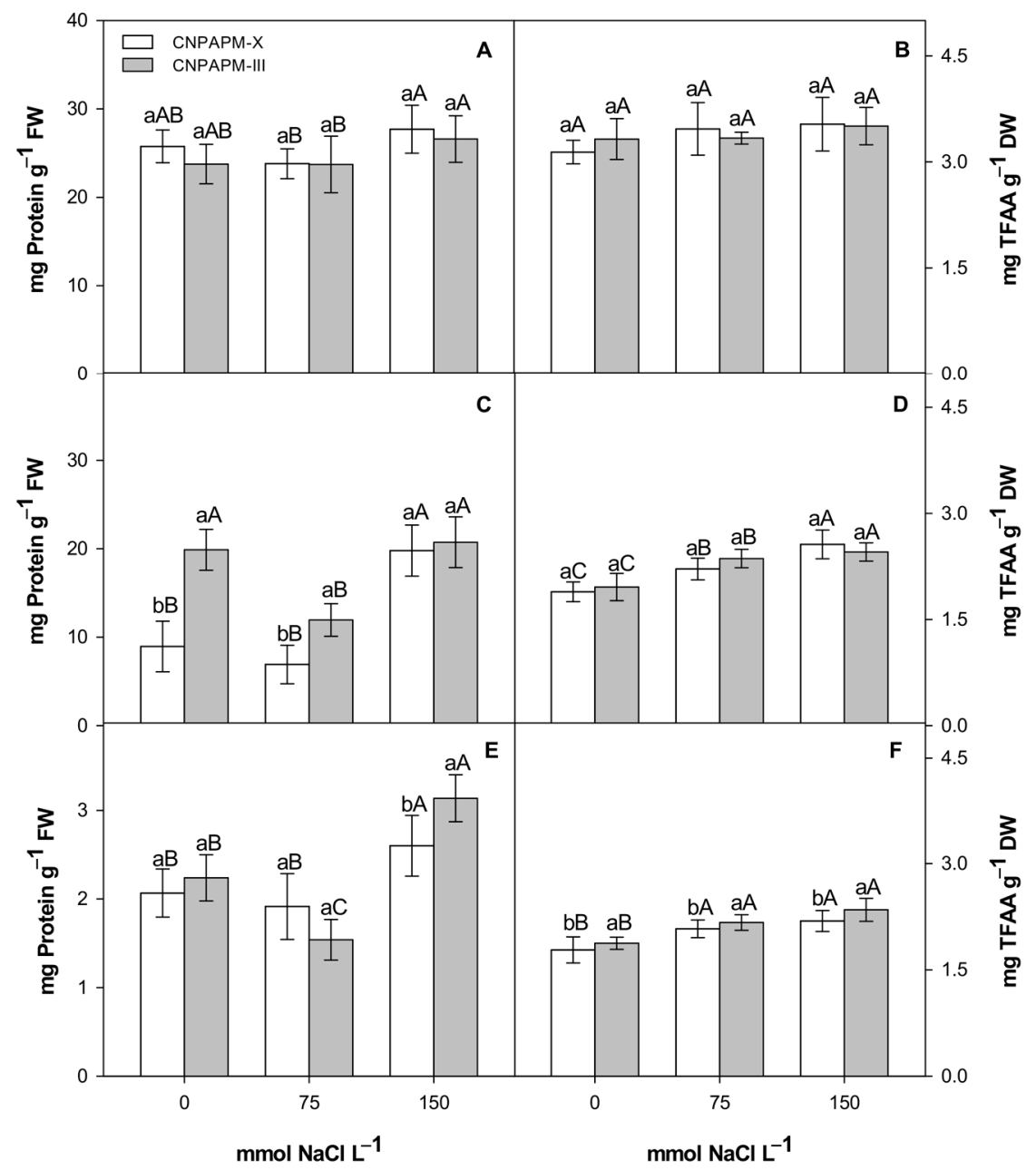

Figure 4. Soluble protein content (SP) and total free amino acids (TFAA) in the leaves (A,B), hypocotyls $(\mathbf{C}, \mathbf{D})$, and roots $(\mathbf{E}, \mathbf{F})$ of Jatropha seedlings on the 8 th DAS after exposure to 0,75 and $150 \mathrm{mM} \mathrm{NaCl}$. Upper case letters on the bars indicate the differences between the doses of $\mathrm{NaCl}$ and lower-case letters indicate differences between genotypes tested by the Tukey test $(p \leq 0.05)$.

In the cotyledon leaves, the total free amino acid (TFAA) content remained unchanged for both genotypes, regardless of the $\mathrm{NaCl}$ concentration (Figure 4B). In the hypocotyl (Figure $4 \mathrm{D})$, for both genotypes there was an increase in the TFAA concentration when the $\mathrm{NaCl}$ levels in the solution increased $(14.55 \%$ at $75 \mathrm{mM}$ and $26.17 \%$ at $150 \mathrm{mM}$ in CNPAPM-X, $17.06 \%$ at $75 \mathrm{mM}$ and $20.19 \%$ at $150 \mathrm{mM}$ in CNPAPM-III). In roots, the TFAA content increased by approximately $26 \%$ and $20 \%$ for CNPAPM-X and CNPAPM-III genotypes, respectively, after exposure to both salt concentrations, in relation to the control groups (Figure $4 \mathrm{~F}$ ).

The neutral lipid content in cotyledon leaves (Figure 5A) showed a significant increase of approximately $34 \%$ in the CNPAPM-III genotype after exposure to both salt treatments, compared to their respective control groups. On the other hand, genotype CNPAPM-X showed a reduction of approximately $26 \%$ in lipid levels, mainly in the moderate salt treatment $(75 \mathrm{mM})$. In the hypocotyls, no significant differences in the lipid concentration were observed for any of the evaluated treatments, independent of the genotype (Figure 5B). 
In the roots, a significant reduction of approximately $8 \%$ for CNPAPM-X and $20 \%$ for CNPAPM-III was observed for both salt treatments (Figure 5C).

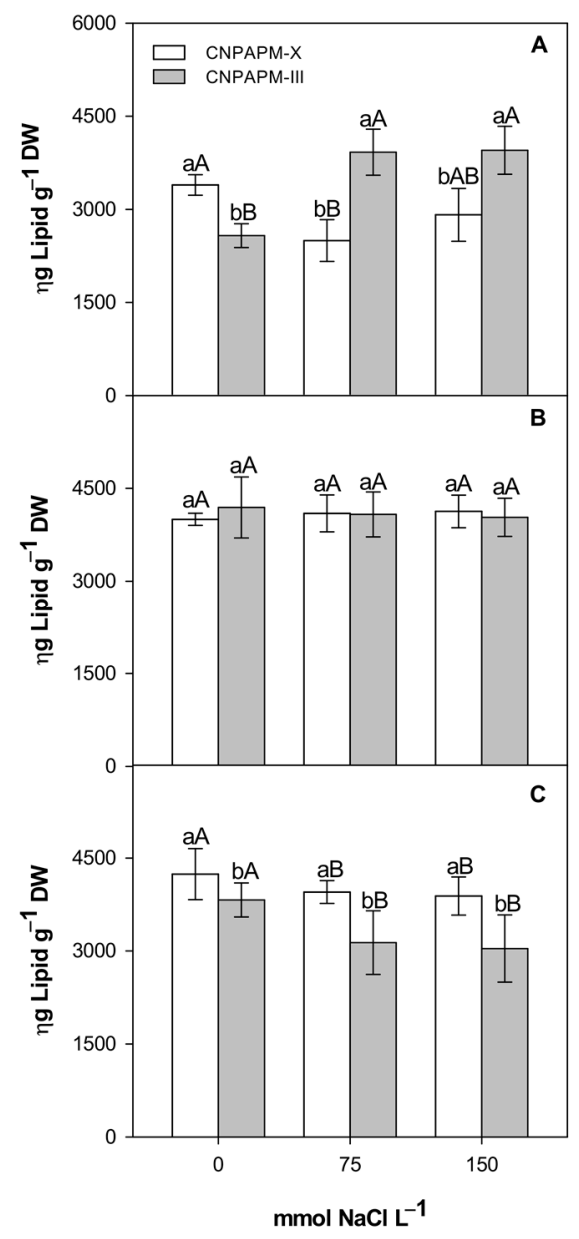

Figure 5. Content of neutral lipids in the leaves (A), hypocotyls (B) and roots (C) of Jatropha seedlings on the 8th day DAS after exposure to 0,75 and $150 \mathrm{mM} \mathrm{NaCl}$. Upper case letters on the bars indicate the differences between the doses of $\mathrm{NaCl}$ and lower-case letters indicate differences between genotypes tested by the Tukey test $(p \leq 0.05)$.

\section{Discussion}

The reduction of FW observed in all the organs of the seedlings in both genotypes may be related to the reduction in water availability in the plant tissues, due to the unavailability of water imposed by the osmotic component of salinity $(\mathrm{NaCl})$ and /or by the ionic stress due to $\mathrm{Na}^{+} / \mathrm{Cl}^{-}$[13-29]. It is possible that the decrease in dry mass percentage that was mainly observed in cotyledon leaves subjected to the more severe concentrations of $\mathrm{NaCl}$ may have occurred in both genotypes because of the inability to convert assimilated carbon into phytomass and /or the use of energy in other physiological processes for the adaptation of Jatropha to salinity. These processes could be related to the regulation of ionic transport and distribution in various organs; the synthesis of organic solutes for osmoregulation and the maintenance of cell membrane integrity [11-13]. The reduction in dry phytomass production in Jatropha seedlings subjected to higher concentrations of $\mathrm{NaCl}$ was also observed by Matsumoto et al. [30], using concentrations above $54 \mathrm{mM}$.

In the cotyledon leaves of Jatropha seedlings, increases in $\mathrm{Na}^{+}$contents were observed at the expense of the $\mathrm{K}^{+}$content. The reduction in the concentration of $\mathrm{K}^{+}$may be related to the increase in the $\mathrm{Na}^{+}$concentration in the external environment because an increase of salinity compromises the absorption of $\mathrm{K}^{+}$. Consequently, it causes a deficiency of this ion that leads to metabolic disturbances resulting from the competition between $\mathrm{Na}^{+}$and 
$\mathrm{K}^{+}$at the same entry sites in cells [31,32]. The reduction in the concentration of $\mathrm{K}^{+}$with the increase of $\mathrm{NaCl}$ concentrations in Jatropha was also observed by Silva et al. [13] and Cunha et al. [10]; and in Cnidoscolus phyllacanthus by Oliveira et al. [33].

The accumulation of $\mathrm{Na}^{+}$ions occurred mainly in the basal organs of the seedling (hypocotyls and roots), with the cotyledon leaves having the lowest concentrations of $\mathrm{Na}^{+}$. It is possible that the accumulation of $\mathrm{Na}^{+}$in these basal structures is a protection mechanism used by the species to preserve the aerial part through the compartmentalization of the ions in vacuoles. This aspect could control the translocation to the shoots of the seedling and reduce probable damage to the photosynthetic apparatus of the leaves [34]. The accumulation of $\mathrm{Na}^{+}$in stems of Euphorbiaceae has already been discussed by other authors $[31,35]$ and is probably related to the stem acting as an $\mathrm{Na}^{+}$-accumulating organ.

The reduction in $\mathrm{Na}^{+}$absorption by roots of the CNPAPM-X genotype, especially at the highest concentration of $\mathrm{NaCl}(150 \mathrm{mM})$, suggests that the genotype did not exhibit retention of the toxic ions in the root cells as a defense mechanism [10]. This result reinforces the hypothesis that the stem acts as the main $\mathrm{Na}+$ mobilization barrier for the leaves of $J$. curcas, functioning as an organ that can accumulate toxic ions.

Considering the $\mathrm{K}^{+} / \mathrm{Na}^{+}$ratio, values below 1 indicate a $\mathrm{Na}^{+}$accumulation over $\mathrm{K}^{+}$, suggesting ionic toxicity in the plant [36]. In Jatropha seedlings, the $\mathrm{K}^{+} / \mathrm{Na}^{+}$ratio is less than 1 in the roots and hypocotyls, and higher than 1 in the leaves. This suggests a possible ionic toxicity and probably the roots, but especially the hypocotyls, were efficient in preventing an excessive accumulation of $\mathrm{Na}^{+}$in the aerial parts of the sapling. This guarantees the maintenance of a $\mathrm{K}^{+} / \mathrm{Na}^{+}$ratio compatible with the requirements for adequate functioning in plant metabolism, including the most severe stress conditions [33].

The increase in TSS concentration has been reported as a component of the osmotic adjustment occurring in plants submitted to saline stress conditions, as observed in Jatropha by Sousa et al. [37], cowpea by Souza et al. [38], and corn by Gomes et al. [39]. The results of this study suggest that at a moderate concentration of $\mathrm{NaCl}(75 \mathrm{mM})$ increased TSS levels were possibly caused by a disruption in photoassimilate mobilization. $\mathrm{NaCl}$ also impairs amylase activity, thereby interfering in the mobilization of starch [40,41]. In addition, reductions in TSS concentrations in the roots of both genotypes could be associated with the inability of the plant to translocate these source organ compounds from the cotyledon leaves into the roots under stress conditions [42,43]. This could also explain the accumulation of TSS in cotyledon leaves in the present study. Furthermore, Reale et al. [41] demonstrated that, in the post-germination stage, J. curcas accumulated starch, especially in the cotyledon leaves and hypocotyl, as a result of photosynthetic activity in these organs. Our results corroborate that $\mathrm{NaCl}$ interferes with the mobilization of starch in the hypocotyl as well as the carbon flux among vegetative organs, as indicated by a consistent accumulation of NRS in cotyledons and decreased concentration in the hypocotyl.

The accumulation of NRS (e.g., sucrose) and RS (e.g., glucose and fructose) in cotyledon leaves suggests a decreased use of these carbohydrates, when growth is inhibited or reduced [44,45]. The increase in NRS and RS production in proportion to the increase of $\mathrm{NaCl}$ concentrations in the seedling establishment phase was also observed in wheat [46].

In this study, it has been observed that there is a large production of NRS in cotyledon leaves, but such sugars appear not to be translocated to the basal organs (hypocotyls and roots). The increase in the concentration of RS and the accumulation of 4.5 times more starch in hypocotyls than in leaves, associated with the reduction of NRS concentration in hypocotyls, suggests that the NRS are being converted into starch. It is also possible that the formed starch is not converted to TSS due to a mismatch in the activity of amylase enzymes, caused by salt stress, which impairs the starch cleavage [47]. Another relevant hypothesis is that there could be a lower demand for TSS in the tissues of the hypocotyls and, for this reason, the conversion of starch into TSS is unnecessary, which contributes to the accumulation of starch in the hypocotyls. The decrease in RS levels in the roots indicates that these carbohydrates, when translocated from the leaves, accumulate in the hypocotyls, which proves the importance of this organ as an accumulating structure not 
only of toxic ions, but also of organic solutes. This function of the stem as an accumulator of substances was also observed in sunflower plants by Rocha et al. [48].

The reduction in the content of hypocotyl and root proteins, only in the genotype CNPAPM-III and at the concentration of $75 \mathrm{mM}$, suggests disruption to protein synthesis, or even an increase of degradation due to the increase in intracellular $\mathrm{Na}^{+}$concentrations [49]. Reductions in protein content due to increased salinity were also observed in sorghum [50] and string bean plants [8].

In contrast, at the concentration of $150 \mathrm{mM}$ there was an increase in the concentration of proteins in the hypocotyls and roots of the CNPAPM-X genotype and only in the roots of the CNPAPM-III genotype. Such an increase could indicate a certain level of tolerance of this species to salinity, since stress-responsive proteins which are responsive to stress may contribute to salinity tolerance. Examples of such proteins are 'chaperones', that play an important role in the protection of stress proteins and 'late embryogenesis abundant proteins', which accumulate in vegetative tissues during periods of drought and are an indication of protection against desiccation [51,52]. The accumulation of proteins under conditions of severe stress in plants has also been reported in Cnidoscolus phyllacanthus by Oliveira et al. [33] and in Hymenea courbaril by Nascimento et al. [53]. The differences observed in the accumulation of proteins, according to the level of salinity studied, suggest that Jatropha seedlings present specific responses to a certain dose of salt, a fact that was also observed by Cunha et al. [10].

An increase in the amino acid concentrations in the hypocotyl and seedling roots of both studied Jatropha genotypes was observed. This process, occurring mainly in the basal organs, suggests a stimulus to nitrogen fixation that may be related to a salinity tolerance [54]. In addition, it is possible that the increase observed in the amino acid content of the hypocotyls of the CNPAPM-III genotype at the concentration of $150 \mathrm{mM}$ $\mathrm{NaCl}$ results from biosynthesis, since there was no evidence of protein degradation. One of the roles of amino acids would be to act as a readily available source of nitrogen and carbon as a way of reversing the effects of salt stress [55]. The accumulation of amino acids in plants subjected to several stresses has been reported previously $[53,56]$. This increase in amino acid level could have a beneficial effect during germination and early seedling development, facilitating stress acclimatization in some species [57].

The increased lipid content observed in cotyledon leaves in the CNPAPM-III genotype could be a consequence of delayed mobilization of lipids with increased salinity. During germination, oilseeds metabolize triacylglycerols by converting them into a more mobile form of carbon in the glyoxalate cycle, where the main enzyme involved is a lipase [57]. Thus, the fact that the metabolism of oleaginous plants works around the mobilization of carbohydrates may justify the low lipid concentration in the various organs studied, compared to the concentration of other macromolecules. However, lipid degradation processes are highly sensitive to stressfactors, including saline stress. The disorder triggered by salinity caused delayed lipid metabolism, thus compromising plant growth, as was observed by Gomes [58] in Copaifera langsdorffii, by Aghaleh et al. [59] in Persian salirconia and Salirconia europaea, and by Alencar [60] in J. curcas L.

The accumulation of carbohydrates and lipids under conditions of saline stress is directly related to the reduction in the growth rate of the seedlings [3]; however, despite the reduction in growth, there was an increase in protein and TFAA levels. The consistent increases in the soluble protein and TFAA pools in the roots are evidence of changes in the protein and amino acid patterns. This suggests a metabolic response of the seedling, likely mediated by gene expression (not considered in this study), to the ionic toxicity and changes in osmolarity of substrate caused by $\mathrm{NaCl}[39,61]$.

In the literature, information is scarce on the relationship between carbohydrate and lipid accumulation and protein and amino acid synthesis. However, it is hypothesized that due to the losses in the energy production pathways, there is a deviation in the route of mobilization by dedicating carbon skeletons to the synthesis of amino acids and 
proteins [62] thus increasing the tolerance of seedlings to saline stress. Further studies are needed to confirm these hypotheses, especially for the Jatropha culture.

\section{Conclusions}

This paper proposes that the responses observed between the two J. curcas genotypes are genotype dependent. In addition, the genotype most adapted to salinity was CNPAPM$\mathrm{X}$, as it was less affected by saline stress during the germination and establishment. Salinity caused the inhibition of lipid mobilization and carbon reserves, factors that, together with the synthesis of proteins and amino acids, contribute to the response of these plants to salinity. Additionally, the accumulation of TFAA and proteins in the hypocotyl and roots as much as of the starch in hypocotyl could have also acted in the metabolic response, though this increase was not able to prevent biomass loss. We suggest that aspect is important and should be the subject of further studies.

Author Contributions: Conceptualization, E.L. and J.M.; methodology, E.L., J.S. and L.G.; formal analysis, A.S., Y.M. and I.S.; data curation, C.M. (Cristiane Macêdo), C.M. (Carlos Meneses) and J.M.; writing-original draft preparation, E.L.; writing—review and editing, C.M. (Cristiane Macêdo), N.A., C.M. (Carlos Meneses) and J.M.; visualization, J.M.; supervision, J.M.; project administration, J.M.; funding acquisition, J.M. All authors have read and agreed to the published version of the manuscript.

Funding: This study was financed in part by the State University of Paraiba grant 001/2021. This study was financed in part by the Coordenação de Aperfeiçoamento de Pessoal de Nível SuperiorBrazil (CAPES)-Finance Code 001.

Institutional Review Board Statement: Not applicable.

Informed Consent Statement: Not applicable.

Acknowledgments: Emannuella Lira, Anselmo Silva, Yuri Melo thank CAPES and CNPq for fellowship support. We thank Luc Marie Felicianus Rouws for critical reviews and native speaker advice.

Conflicts of Interest: The authors declare no conflict of interest.

\section{References}

1. Mittler, R.; Blumwald, E. Genetic engineering for modern agriculture: Challenges and perspectives. Ann. Rev. Plant Biol. 2010, 61, 443-462. [CrossRef] [PubMed]

2. Mudalkar, S.; Sreeharsha, R.V.; Reddy, A.R. Involvement of glyoxalases and glutathione reductase in conferring abiotic stress tolerance to Jatropha curcas L. Environ. Exp. Bot. 2017, 134, 141-150. [CrossRef]

3. Coelho, D.S.; Simões, W.L.; Mendes, A.M.S.; Dantas, B.F.; Rodrigues, J.A.S.; Souza, M.A. Germination and initial growth of varieties of forage sorghum under saline stress. Rev. Bras. Eng. Agric. Ambient. 2014, 18, 25-30. [CrossRef]

4. Pedrotti, A.; Chagas, R.M.; Ramos, V.C.; Prata, A.P.N.; Lucas, A.A.T.; Santos, P.B. Causes and consequences of the process of soil salinization. Rev. Eletr. Gest. Educ. Tecnol. Amb. 2015, 19, 1308-1324.

5. Silva, E.N.; Vieira, S.A.; Ribeiro, R.V.; Ponte, L.F.; Ferreira-Silva, S.L.; Silveira, J.A. Contrasting physiological responses of Jatropha curcas plants to single and combined stresses of salinity and heat. J. Plant Growth Regul. 2013, 32, 159-169. [CrossRef]

6. Singh, R.A.; Kumar, M.; Haider, E. Synergistic cropping of summer groundnut with Jatropha curcas-A new two-tier cropping system for Uttar Pradesh. J. SAT Agric. Res. 2007, 5, 1-2.

7. Pereira-Filho, J.L.; Gerônimo-Neto, P.S.; Monteiro, P.M.; Ferreira, J.M.S.; Pinheiro, A.A.; Rodrigues, C.D.P.; Vilanova, C.M. Technological prospection on the biological effects of plants of the Jatropha genus. Res. Soc. Dev. 2020, 9, 1-11. [CrossRef]

8. Calvet, A.S.F.; Pinto, C.M.; Lima, R.E.M.; Maia-Joca, R.P.M.; Bezerra, M.A. Growth and solute accumulation in cowpea irrigated with waters rising salinity in different stages of development. Rev. Irrig. 2013, 18, 148-159. [CrossRef]

9. Zhang, L.; Zhang, C.; Wu, P.; Chen, Y.; Li, M.; Jiang, H.; Wu, G. Global analysis of gene expression profiles in physic nut (Jatropha curcas L.) seedlings exposed to salt stress. PLOS ONE 2014, 9, e97878. [CrossRef] [PubMed]

10. Cunha, P.C.; Mendes, B.S.S.; Oliveira Filho, R.A.; Camara, T.R.; Willadino, L.G. Growth, synthesis of organic solutes and ionic balance in seedlings of physic nut under saline stress. Rev. Caatinga 2013, 26, 46-52.

11. Silva, E.N.; Ribeiro, R.V.; Ferreira-Silva, S.L.; Vieira, S.A.; Ponte, L.F.; Silveira, J.A. Coordinate changes in photosynthesis, sugar accumulation and antioxidative enzymes improve the performance of Jatropha curcas plants under drought stress. Biomed. Bioeng. 2012, 45, 270-279. [CrossRef]

12. Marques, E.C.; Freitas, V.S.; Bezerra, M.A.; Prisco, J.T.; Gomes-Filho, E. Effects of salt stress on germination, emergence and establishment of dwarf-cashew seedling. Rev. Ciênc. Agron. 2011, 42, 993-999. [CrossRef] 
13. Silva, E.N.; Silveira, J.A.G.; Rodrigues, C.R.F.; Lima, C.S.; Viégas, R.A. Contribution of organic and inorganic solutes to osmotic adjustment of physic nut under salinity. Pesq. Agropec. Bras. 2009, 44, 437-445. [CrossRef]

14. Galdino, L.S.; Lira, E.H.A.; Sousa, V.F.O.; Souza, J.M.; Maia, J.M.; Costa, P.O.C.; Arriel, N.H.C. Standardization of NaCl doses for saline stress induction in Jatropha curcas L. Rev. Ciênc. Agric. 2017, 40, 319-332. [CrossRef]

15. Martins, C.C.; Machado, C.G.; Cavasini, R. Temperature and substrate for the germination test of physic nut seeds. Ciênc. Agrotec. 2008, 32, 863-868. [CrossRef]

16. Pascuali, L.C.; Silva, F.S.; Porto, A.G.; Silva Filho, A.; Meneghello, G.E. Germination of physic nut seeds in different temperatures, light and substrates. Semina Ciênc. Agric. 2012, 33, 1435-1440. [CrossRef]

17. Pimenta, A.C.; Zuffellato-Ribas, K.C.; Laviola, B.G. Morphology of fruits, seeds and seedlings of Jatropha curcas. Rev. Flor. 2014, 44, 73-80. [CrossRef]

18. Morais, E.B.S.D. Standardization of the Germination Test and Qualify of Physic Nut (Jatropha curcas L.). Ph.D. Thesis, Universidade Estadual de Montes Claros, Montes Claros, Brazil, 2008.

19. Malavolta, E.; Vitti, G.C.; Oliveira, A.S. Avaliação do Estado Nutricional das Plantas: Princípios e Aplicações, 1st ed.; Associação Brasileira para Pesquisa do Potássio e do Fosfato: Piracicaba, Brazil, 1989; pp. 115-143.

20. Dubois, M.; Gilles, K.A.; Hamilton, J.K.; Rebers, P.A.; Smith, F. Colorimetric method for determination of sugars and related substances. Anal. Chem. 1956, 28, 350-356. [CrossRef]

21. Morris, D.L. Quantitative determination of carbohydrates with Dreywood's anthrone reagent. Science 1948, 107, 254-255. [CrossRef]

22. Yemm, E.W.; Willis, A.J. The estimation of carbohydrates in plant extracts by anthrone. Biochem. J. 1954, 57, 508-514. [CrossRef]

23. Passos, L.P. Métodos Analíticos e Laboratoriais em Fisiologia Vegetal, 1st ed.; Embrapa: Coronel Pacheco, Brazil, 1996 ; pp. 90-115.

24. Mccready, R.M.; Gugoolz, J.; Silveira, V.; Owens, H.S. Determination of starch and amylose in vegetables: Application to peas. Anal. Chem. 1950, 22, 1156-1158. [CrossRef]

25. Bradford, M.M.A. Rapid and sensitive method for the quantification of microgram quantities of protein utilizing the principle of dye binding. Anal. Biochem. 1976, 72, 248-254. [CrossRef]

26. Peoples, M.B.; Faizah, A.W.; Rerkasem, B.G.; Herridge, D.F. Methods for Evaluating Nitrogen Fixation by Nodulated Legumes in the Field, 1st ed.; Australian Center for International Agricultural Research: Camberra, Australia, 1989; pp. $210-235$.

27. Baumgärtner, T.R.S.; Burak, J.A.M.; Zanin, G.M.; Baumgärtner, D.; Sébastien, N.Y.; Arroyo, P.A. Different methods for extracting oil from the microalga Scenedesmus accuminatus for biodiesel production. Br. J. Anal. Chem. 2013, 10, 441-445.

28. Banzatto, D.A.; Kronka, S.D. Experimentação Agrícola, 4th ed.; FUNEP: Jaboticabal, Brazil, 2013.

29. Gadelha, C.G.; Souza Miranda, R.; Alencar, N.L.M.; Costa, J.H.; Prisco, J.T.; Gomes-Filho, E. Exogenous nitric oxide improves salt tolerance during establishment of Jatropha curcas seedlings by ameliorating oxidative damage and toxic ion accumulation. J. Plant. Physiol. 2017, 212, 69-79. [CrossRef] [PubMed]

30. Matsumoto, H.; Yeasmin, R.; Kalemelawa, F.; Watanabe, T.; Aranami, M.; Nishihara, E. Evaluation of NaCl tolerance in the Physical Reduction of Jatropha curcas L. seedlings. Agric. Sci. 2014, 2, 23-35. [CrossRef]

31. Rodrigues, C.R.F.; Silveira, J.A.G.; Silva, E.N.; Dutra, A.T.B.; Viégas, R.A. Potassium transport and partitioning alleviates toxic effects of sodium on young physic nut plants. Rev. Bras. Ciênc. Sol. 2012, 36, 223-232. [CrossRef]

32. Hishida, M.; Ascencio, F.; Fujiyama, H.; Orduno-Cruz, A.; Endo, T. Response to salt stress in growth water relations and ion content of Jatropha curcas and J. cinerea seedlings. Intercienc. J. 2013, 38, 289-304.

33. Oliveira, M.D.M.; Bezerra, L.L.; Dantas, C.V.S.; Voigt, E.L.; Maia, J.M.; Macêdo, C.E.C. The role of xylopodium in Na ${ }^{+}$exclusion and osmolyte accumulation in faveleira [Cnidoscolus phyllacanthus (M. Arg.) Pax et K. Hoffm] under salt stress. Acta Phys. Plant. 2014, 36, 2871-2882. [CrossRef]

34. Lopes, J.C.; Macedo, C.M.P. Germination of Brassica pekinensis affected by seed moisture content, substrate and saline stress. Rev. Bras. Sem. 2008, 30, 79-85. [CrossRef]

35. Lima, G.S.; Nobre, R.G.; Gheyi, H.R.; Soares, L.A.A.; Pinheiro, F.W.A.; Dias, A.S. Growth, content of sodium, chlorideand ion relation in castor bean under salt stress and nitrogen fertilization. Comun. Scient. 2015, 6, 212-223.

36. Maathuis, F.J.M.; Amtmann, A. $\mathrm{K}^{+}$nutrition and $\mathrm{Na}^{+}$toxicity: The basis of cellular $\mathrm{K}^{+} / \mathrm{Na}^{+}$rations. Ann. Bot. 1999, 84, 123-133. [CrossRef]

37. Sousa, A.E.C.; Silveira, J.A.G.; Gheyi, H.R.; Lima Neto, M.C.; Lacerda, C.F.; Soares, F.A.L. Gas exchange and contents of carbohydrates and nitrogen compounds in physic nut irrigated with saline water and wastewater. Pesq. Agropec. Bras. 2012, 47, 1428-1435. [CrossRef]

38. Souza, R.P.; Machado, E.C.; Silveira, J.A.G.; Ribeiro, R.V. Photosynthesis and accumulation of solutes in cowpea plants subjected to salinity. Pesq. Agropec. Bras. 2011, 46, 586-592. [CrossRef]

39. Gomes, K.R.; Amorim, A.V.; Ferreira, F.J.; Filho, F.L.A.; Lacerda, C.F.; Gomes-Filho, E. Physiology and growth responses of maize subjected to salt stress in different cultiving spacings. Rev. Bras. Eng. Agríc. Ambient. 2011, 15, 365-370. [CrossRef]

40. Lin, C.C.; Kao, C.H. NaCl stress in rice seedling: Starch mobilization and the influence of gibberellic acid on seedling growth. Bot. Bull. Acad. Sin. 1995, 36, 169-173.

41. Adda, A.; Regagba, Z.; Latigui, A.; Merah, O. Effect of salt stress on $\alpha$-amylase activity, sugars mobilization and osmotic potential of Phaseolus vulgaris L. Seeds var. 'Cocorose' and 'Djadida' during Germination. J. Biol. Sci. 2014, 14, 370-375. [CrossRef] 
42. Dkhil, B.B.; Denden, M. Salt stress induced changes in germination, sugars, starch and enzyme of carbohydrate metabolism in Abelmoschus esculentus L. (Moench.) seeds. Afr. J. Agric. Res. 2010, 5, 408-415.

43. Reale, L.; Ricci, A.; Ferranti, F.; Torricelli, R.; Venanzoni, R.; Falcinelli, M. Cytohistological analysis and mobilization of reserves in Jatropha curcas L. Seed. Crop. Sci. 2012, 52, 830-835. [CrossRef]

44. Munns, R.; Weir, R. Contribution of sugars to osmotic adjustment in elongating and expanded zones of wheat leaves during moderate water deficits at two light levels. Aust. J. Plant Phys. 1981, 8, 93-105. [CrossRef]

45. Sturm, A.; Tang, G.Q. The sucrose-cleaving enzymes of plants are crucial for development, growth and carbon partitioning. Trends Plant Sci. 1999, 4, 401-407. [CrossRef]

46. Lin, J.; Li, X.; Zhang, Z.; Yu, X.; Gao, Z.; Wang, Y.; Wang, J.; Li, Z.; Mu, C. Salinity-alkalinity tolerance in wheat: Seed germination, early seedling growth, ion relations and solute accumulation. Afr. J. Agric. Res. 2012, 7, 467-474. [CrossRef]

47. Hussain, S.; Khaliq, A.; Tanveer, M.; Matloob, A.; Hussain, H.A. Aspirin priming circumvents the salinity-induced effects on wheat emergence and seedling growth by regulating starch metabolism and antioxidant enzyme activities. Acta Physiol. Plant. 2018, 40, 68. [CrossRef]

48. Rocha, J.G.; Ferreira, L.M.; Tavares, O.C.H.; Santos, A.M.; Souza, S.R. Nitrogen absorption kinetics and accumulation of soluble nitrogenous fractions and sugars in sunflower. Pesq. Agropec. Trop. 2014, 44, 381-390. [CrossRef]

49. Silveira, J.A.G.; Viégas, R.D.; Rocha, I.M.A.; Moreira, A.C.D.M.; Moreira, R.D.; Oliveira, J.T.A. Proline accumulation and glutamine synthetase activity are increased by salt-induced proteolysis in cashew leaves. J. Plant Phys. 2003, 160, 115-123. [CrossRef] [PubMed]

50. Lobo, A.K.M.; Martins, M.O.; Lima-Neto, M.C.; Bonifácio, A.; Silveira, J.A.G. Nitrogenous compounds and carbohydrates in sorghum subjected to salinity and combinations of nitrate and ammonium. Rev. Ciênc. Agron. 2011, 42, 390-397. [CrossRef]

51. Mohammadkhani, N.; Heidari, R. Effects of drought stress on soluble proteins in two maize varieties. Turk. J. Biol. 2008, 32, 23-30.

52. Benko-Iseppon, A.M.; Cavalcanti, N.M.S.; Berlarmino, L.C.; Bezerra-Neto, J.P.; Amorim, L.L.B.; Ferreira-Neto, J.R.; Pandolfi, P.; Azevedo, H.M.S.A.; Silva, R.L.O.; Santos, M.G.; et al. Exploration of Genes for Resistance to Drought and Salinity in Native and Cultivated Plants. Rev. Bras. Geogr. Fís. 2011, 6, 1112-1134.

53. Nascimento, H.H.C.; Santos, C.A.; Freire, C.S.; Silva, M.A.; Nogueira, R.J.M.C. Osmotic adjustment in jatobá seedlings subjected to salinity in hydroponic medium. Rev. Árv. 2015, 39, 641-653. [CrossRef]

54. Mansour, M.M.F. Nitrogen containing compounds and adaptation of plants to salinity stress. Biol. Plant. 2000, 43, 491-500. [CrossRef]

55. Handa, S.; Bressan, R.A.; Handa, A.K.; Carpita, N.C.; Hasegawa, M. Solutes contributing to osmotic adjustment to plant cells adapted to water stress. Plant. Physiol. 1983, 73, 834-843. [CrossRef]

56. Melo, Y.L. Agronomic Performance and Characterization of Sunflower (Helianthus annuus L.) Genotypes for Phenological, Physiological and Biochemical Markers in Two Edaphoclimate Microregions of Rio Grande do Norte. Ph.D. Thesis, Universidade Federal Rural do Semi-Árido, Mossoró, Brazil, 2012.

57. Krasensky, J.; Jonak, C. Drought, salt, and temperature stress-induced metabolic rearrangements and regulatory networks. J. Exp. Bot. 2012, 63, 1593-1608. [CrossRef] [PubMed]

58. Gomes, A.D.V.; Leite, M.J.H.; Freire, A.L.O. Accumulation of organic solutes in plants munquêm (Albizia inundala (Mart)) subjected to salt stress at different levels of sodium chloride. Rev. Verde Agroecol. Desenv. Sustent. 2012, 7, 54-56. [CrossRef]

59. Aghaleh, M.; Niknam, V.; Ebrahimzadeh, H.; Razavi, K. Effect of salt stress on phisyological and antioxidative responses in two species of Saliconia (S. persica and S. europaea). Acta Physiol. Plant. 2011, 33, 1261-1270. [CrossRef]

60. Alencar, N.L.M. Mobilização de Reservas Endospérmicas de Pinhão-Manso Durante a Germinação e Desenvolvimento da Plântula sob Condições de Estresse Salino. Master's Thesis, Universidade Federal do Ceará, Fortaleza, Brazil, 2014.

61. Ghosh, D.; Xu, J. Abiotic stress responses in plant roots: A proteomics perspective. Front. Plant. Sci 2014, 5, 1-13. [CrossRef] [PubMed]

62. Tester, M.; Davenport, R. $\mathrm{Na}^{+}$tolerance and $\mathrm{Na}^{+}$transport in higher plants. Ann. Bot. 2003, 91, 502-527. [CrossRef] 